\title{
The Politics of Austerity and Public Policy Reform in the EU
}

\author{
Stella Ladi \\ Queen Mary University of London
}

\author{
Dimitris Tsarouhas \\ Bilkent University
}

The European Union (EU) is at a critical juncture that will either trigger further integration or reinforce a mode of intergovernmental cooperation. The spread of market pressure to a growing number of states demonstrates that the crisis needs to be dealt with at the European and not just the national level. Up to now the "politics of extreme austerity' has been the mainstream recipe promoted to and adopted by member states. The measures are tougher in those countries where there has been external financial assistance (i.e. Greece, Portugal and Ireland) but the rest of Europe is following suit (e.g. Italy and the UK). This introduction outlines the key directions of EU reforms to put into context the more specific cases discussed elsewhere in this symposium. The strengths and weaknesses of the theoretical frameworks employed in the articles are discussed to demonstrate the lessons that the crisis offers for our well-established public policy models and to highlight avenues for further research. Two main arguments are advanced: first, the crisis calls for an interdisciplinary approach to comprehend its full extent and deal with it efficiently; and second, the current political trajectory of the EU calls for urgent changes to strengthen its cohesion and long-term viability.

Keywords: EU; austerity politics; Eurozone crisis; governance

On the eve of the financial crisis in 2008, the European Union and its most prized achievement - the euro - appeared safe. The Commission described the euro as a 'resounding success' (European Commission, 2008, p. 3) and there was little indication that the Eurozone would soon be battling for its credibility and, indeed, survival. Following the outbreak of the financial crisis, however, EU member states have been confronted with a series of hard policy dilemmas. To save individual banks and thus the banking system from collapse, a series of financial commitments, guarantees and bailout packages were agreed that led to massive increases in budget deficits and debt levels. In combination with sluggish growth and growing unemployment rates, the EU and the Eurozone in particular have resorted to initially short-term crisis management techniques and often desperate attempts to reassure the markets about the viability of Economic and Monetary Union (EMU).

The banking and financial crisis thus mutated into a debt crisis, and since 2010 to a full-blown economic crisis with far-reaching political, economic and social repercussions. The European Union is now trying to perform several roles simultaneously: provide assistance to countries in need of financial aid; reinforce conditionality by building on the Stability and Growth Pact (SGP) by adding new institutional features; and enhance integration by formulating new policies and inventing new institutional mechanisms.

It is the latter part of the EU's work that concerns us here. Since the onset of the crisis, Europe has proceeded with the creation of new institutional mechanisms to contain and/or mitigate the effects of the crisis. Some of the new policy instruments agreed upon or currently debated will, however, have long-lasting consequences that 
affect the very nature of the EU project as they imply a shift in the balance between national and EU competences and stronger EU surveillance powers over member state policies. More importantly, these initiatives reveal the political balance of power in the EU as well as the preferred political and economic direction of the EU in years to come. This policy direction is of paramount significance despite the lack of attention paid to it in the context of successive 'crisis summits', the ongoing speculation over a possible Greek exit from the Eurozone and the clouds of uncertainty that hang over the EU as a whole.

The depth of the Eurozone crisis and the efforts to contain it not only inform a series of political choices, but also force us to rethink our theoretical approaches to integration and to public policy change. Long-held convictions and much-discussed paradigms and approaches are now called into question, and the effects of the crisis make it all the more urgent to learn lessons in the wake of important shifts in EU thinking. In this article, we discuss the theoretical frameworks presented in the symposium's other contributions from a critical perspective in order to draw lessons from their application, as well as to highlight avenues for further research and their policy implications.

We begin with an outline of the institutional reforms and changes agreed or set in motion since 2008. We then link the theoretical approaches discussed elsewhere in this symposium with the institutional and political reforms introduced at European and member state levels, trying to derive useful public policy lessons. In the final part we analyse the salience of these changes with regard to the future of the EU and discuss its future political trajectory.

\section{A New EU Governance Architecture: Policy Reform since 2009}

The onset of the crisis found the member states unprepared to deal with it. Today it is easily forgotten that back in 2008-9 few people foresaw the depth of the crisis and the extraordinary amount of money, resources and EU Council summits that would be required to bail out financial institutions. One recent estimate suggests that member states have provided state aid to financial institutions in the range of $€ 4.5$ trillion, which represents 37 per cent of EU gross domestic product (GDP) (Degryse, 2012, p. 79).

Averting a collapse of precious financial institutions meant that the EU, and the Eurozone in particular, found themselves caught in a debt and deficit trap from which they have yet to emerge. However, little attention has been paid (by the EU institutions as much as by analysts and commentators) to the fact that prior to the crisis the vast majority of EU member states were performing very positively with regard to both their debt and deficit levels. With the exception of Greece - a country whose economic management skills left a lot to be desired over decades (Tsarouhas, 2012) - other members were able to achieve consistent budget surpluses in the period 1999-2007. This includes Spain and Ireland, both of which have subsequently received financial assistance from the EU. The overall picture for the EU-27 is unambiguous: in 2007 the EU-27 debt and deficit levels amounted to 0.9 and 59 per cent, respectively - comfortably within the margins determined by the Maastricht Criteria and the SGP (Degryse, 2012, pp. 69-70). Successive bailouts and stimulus packages to avoid an economic Armageddon led to a rapid increase in these indices and a frantic, often chaotic attempt by EU institutions to contain the crisis. 
Over the last four years the EU has created a host of new policy instruments, both formal and informal. More importantly, central institutions such as the European Commission, the European Council and the European Central Bank (ECB) have, in the course of this process, acquired new, substantial powers of surveillance and potential sanctioning over member states. Furthermore, these new surveillance and sanctioning powers are accompanied by the imposition (for bailout states) or 'strong encouragement' (for everyone else) to proceed with public policy reforms, particularly in the sphere of social and labour market policy. Finally, all of this has occurred in the context of austerity, which has been consistently exercised by member states since 2010 and has greatly contributed to the current economic and unemployment crisis in most EU member states.

Ironically, perhaps, the early phase of the crisis proved to be a Keynesian moment. In 2008 state after state chose to partly nationalise financial institutions (UK), unleash rescue plans (France, Germany) or offer special funding to the financial system (Spain) (Degryse, 2012, p. 19). For a brief moment, the discrediting of the existing economic consensus opened new avenues of thinking with regard to financial market regulation and state intervention. Yet by late 2009/early 2010 the Eurozone economies were subjected to consecutive downgrading of their debt by the world's three largest rating agencies. What followed was a series of crisis summits and policy initiatives to contain the growing fire.

First, in 2010 a new unofficial institution was created. The 'Euro Summit' brings together the heads of state and government of Eurozone members. Speculation over the creation of a Eurozone budget (Gros, 2012) reinforces the salience of this unofficial body whose existence is not laid out in any EU treaty. Second, the EU has created three new financial assistance mechanisms that have rearranged the surveillance and supervision mechanisms of different institutions. The assistance mechanisms are the European Financial Stability Facility (EFSF), the European Financial Stabilisation Mechanism (EFSM) and the European Stability Mechanism (ESM). Despite their differences, all three bodies build on the Medium-Term Financial Assistance (MTFA) that helped support nonEurozone states with balance-of-payments difficulties. All three instruments are modelled on the International Monetary Fund (IMF), with the EFSF and ESM in particular linked to financial conditionality. Moreover, their creation means that the Commission is now a major player in the process of activating and implementing financial assistance as it is mandated to negotiate the macroeconomic adjustment programme of states and monitor compliance with it (Salines et al., 2012, pp. 675-7). Third, the EU has sought to reinforce economic governance, reform the SGP and institutionalise the 'golden rule' of balanced budgets. The most important instruments to achieve these aims are: (1) the six-pack of five Regulations and one Directive along with the European Semester, which intensify macroeconomic surveillance over member states; (2) the Euro Plus Pact, which reinforces economic policy coordination and imposes stricter fiscal discipline on member states; and (3) the Fiscal Compact, which obliges states to insert into their legal bodies and/or constitutions the rule of balanced budgets. All of these institutional changes have occurred in the context of austerity policy and have been observed in the EU almost without exception since 2010. 
Overall, these reforms point to a changing landscape in EU governance. The Commission and (to some extent) the ECB are now tasked with the supervision, monitoring and implementation of macroeconomic adjustment programmes, including the revision of budgetary plans by member states deemed to be in breach of the golden rule. Furthermore, the EU will now oversee public policy reforms, particularly in the fields of pensions, healthcare, industrial relations law and public administration. Although member states are still in charge of reform, the content of the reforms have to be compatible with the priorities set out by the Council and the Commission in the reinforced economic governance package, including the Annual Growth Survey (AGS), which is part of the European Semester.

In the context of the empirical record discussed above, we now turn to the theoretical lessons we need to learn in order to understand the crisis, and we link these to the rest of the contributions in this symposium.

\section{Rethinking Theory}

One of the key aims of this symposium is to reconsider the theoretical tools available for understanding political and policy responses to the Eurozone crisis. Current EU developments, as well as national reactions discussed elsewhere in the symposium, force us to revive and redesign classic theories such as corporatism (see Jordana, 2014), but also to rethink and advance more recent approaches such as Europeanisation (see Saurugger, 2014). A crucial point to be made is that interdisciplinary research and the exchange of approaches, data and results across the social sciences is a sine qua non given the increasing complexity of crises. The articles in this symposium draw upon the disciplines of politics, public policy analysis, economics, sociology, international relations, international political economy and EU studies, showing that it is exactly this plurality that can lead to theoretical innovation and the generation of valuable empirical data.

The first article, by Sabine Saurugger, provides a valuable starting point in that it sets out the conceptual basis upon which to study the case studies outlined elsewhere. The article concerns the study of Europeanisation and of the EU polity in light of the current crisis. Saurugger convincingly claims that the resistance of EU member states to austerity measures and other policy reforms that have been imposed - arguably as a response to the crisis - shows that Europeanisation is not simply a top-down process. More focus should be placed on circular Europeanisation (top-down, but also bottom-up), which is acknowledged theoretically but often neglected empirically. Such a focus, which builds upon existing research on time and discourse, will allow for a deeper understanding of the significance of the political aspects of Europeanisation. Her argument is compatible with similar attempts to explore the changing face of the relationship between the EU and its member states. New additions to the literature already engage with terms such as 'coercive' or 'fast-forward' Europeanisation, which is characterised by an intensification of hard mechanisms of Europeanisation (Ladi, 2014; Ladi and Graziano, 2014). Given the political conundrum existing in most member states, an increase in hard mechanisms would unavoidably augment resistance at the national level and therefore lead the EU polity into a vicious circle of decreasing trust - a process that has already begun in a number of EU states. 
The need for interdisciplinary research in order to gain an in-depth understanding of the crisis and its consequences and also in order to inform policy making is highlighted in the next article by Antigone Lyberaki and Platon Tinios (2014). Their analysis focuses on the impact that the financial crisis and the subsequent austerity policy response have had on both the formal and the informal welfare state in Greece. Theoretically, this is a very interesting endeavour because it draws attention to already existing tools and the way they ought to be developed in order to understand policy failure. Specifically, this contribution reminds us that the study of social networks and more particularly social capital needs to be combined with the study of public finance. Lyberaki and Tinios show how a policy measure such as a tax increase squeezes the informal welfare state by putting pressure on the family budget and its ability to offer care for the elderly, children and other vulnerable groups. Consequently, the demand for funds derived from the formal welfare state increases. Combining economic analysis with social networks theory provides invaluable information on transaction costs (Davern, 1997). Such information can enlighten the study of policy failure and success and also be of practical use to policy makers in their attempt to contain the consequences of the economic crisis on those parts of the population most affected.

A different but equally significant issue that has arisen due to the urgency of the financial crisis is the availability of reliable data in order to understand social trends and hence inform policy making. In their article, Manos Matsaganis and Chrysa Leventi (2014) demonstrate the effectiveness of the microsimulation approach in measuring poverty and social inequality at an early stage. Their study concentrates on the impact of the crisis and of austerity policies upon poverty and social inequality in Greece. They find a dramatic rise in poverty rates and a less pronounced but still significant increase in inequality rates. Methodologically, it is important to note the novelty of microsimulation, which can provide results similar to more classical surveys based on simulation of tax and benefits data (Figari et al., 2012). The importance of an interdisciplinary approach is once again demonstrated here. If economic analysis can speed up the provision of reliable data on key social indicators such as poverty and inequality, then public policy analysis can also follow with more accurate explanations of the immediate outcomes of policy reforms as well as with feasible alternatives to extreme austerity measures in dealing with the crisis.

The final article of this symposium alerts us to the topicality of corporatist theory. Jacint Jordana (2014) describes public policy change in Spain as policy dismantling, and highlights that policies that do not have corporatist coalitions to defend them have proven to be the most fragile and thus open to intrusive change (e.g. child policy and active labour market policy). Jordana demonstrates that corporate coalitions such as elite professional public servants and the local financial community have managed to diminish the damage of budget cuts in their sectors in comparison to less privileged groups. $\mathrm{He}$ contends that this is because of the lack of regulation and consequent more long-term change in these sectors. His comparison of Spain's current structural problems with problems that the country faced before its entry into the Eurozone perfectly fits Carlos Molina and Martin Rhodes' (2002) analysis on the past, present and future of corporatism. Molina and Rhodes argue that corporatism needs to be studied and under- 
stood more as a system of policy making than as a structure of interest representation. To simply assume the end of corporatism because of globalisation, the EMU or indeed the current pressures being faced by European states limits our understanding of winners and losers in the ongoing wave of public policy reforms. Jordana's article offers an entry point into the incorporation of corporatist relations in their more flexible (e.g. networks) rather than formal (e.g. tripartite bargaining) format in explaining change.

\section{Rethinking Practice: The Future of the EU}

The financial crisis provides fertile ground for reconsidering existing theoretical schemes for analysing the crisis. It points to the limitations of an inadequate cross-fertilisation between disciplines, and exposes the fallacy of nationally driven methodological approaches in the face of systemic failures at the heart of the EU project. Yet it is clear that the empirical, everyday aspect of the crisis deserves equal attention - not least because this is a crisis unlike previous ones. Having started as a failure of regulation, it has mutated into a banking, then economic and ultimately a political crisis. The latter aspect of the crisis is the most lethal one, and failing to deal with it appropriately may come to signify the beginning of the end of the EU project. Rising levels of Euroscepticism across much of the EU testify to the fragility of the current political settlement and call for new responses in the wake of popular dissatisfaction with the EU's course of action to date. In this context then, what is the normative framework of reform that the EU ought to strive for, and what are the prospects for realising such reforms?

As outlined in the first section, the EU has taken steps towards closer policy coordination, including the establishment of a form of banking union, to deal with such crises better the next time they appear. In October 2013, a Single Supervisory Mechanism (SSM) comprising the ECB and member states' supervisory authorities was agreed. Two months later and in addition to a single resolution fund for banks, a Single Resolution Mechanism (SRM) has also been proposed by the Commission. The 'general approach' therein was accepted by the Council in December 2013 although this was the result of a compromise that explicitly mentions the need for an intergovernmental agreement on the functioning of the single resolution fund (Council of the European Union, 2013). Negotiations with the European Parliament are the next step. Moreover, new surveillance mechanisms have been introduced and the ability of member states to avoid compliance has been drastically curtailed (Tsoukalis, 2012). In the short run, the Eurozone has survived and the EU continues to muddle through.

There are, however, two fundamental problems that have important empirical as well as theoretical implications. They are linked and their solution is a sine qua non for the future of the EU. The first and most immediate problem relates to the lack of consensus on the political measures needed to lift the EU out of the crisis or to provide the stability and political space necessary to debate the future of integration in earnest and in good faith. This is a problem that has remained unaddressed since the crisis began - not least because the lack of consensus exists both between and within member states. In country after country, the ballot box returns politicians deeply critical of the austerity course chosen since the crisis began. Moreover, many of those rejecting austerity go a step 
further and call into question the EU itself. This is the latest warning to the EU that politics as usual will no longer do. That may have worked in the past, but muddling through and expecting the storm to go away will not be sufficient this time. Most worrying of all is the failure to recognise this tendency or to debate it in the open. A technocratic approach has been the default option till now, leading to further estrangement between the governing and the governed at EU level (Overbeek, 2012, pp. 44-5).

The second problem is the paradoxical phenomenon of top-down Europeanisation and the centralised coordination of policies, alongside a clear turn towards intergovernmentalism in the decision-making process. The compromise reached in the Council on the single resolution fund is a perfect example of the continuous wish by some member states to proceed with EU reform along intergovernmentalist lines. Negotiations with the European Parliament (EP) on reaching a mutually acceptable solution will be tough, as stated by the EP President. A particularly thorny aspect of these negotiations could be the fact that the fund responsible for bank closures now appears beyond the scope of the EP's handling power (O'Donnell, 2014).

This complicates the future of the EU - not least because it allows for the old problem of the 'democratic deficit' to resurface, only in even sharper form. Moreover, previous decisions outlined in the first section have also been an almost exclusively intergovermental affair, with Germany providing most of the input and design (seconded by other member states whenever necessary). The new policy measures have been imposed on member states, their electorates and parliaments. The latter have every right to feel powerless in the face of policies designed for the 'collective good', and yet they are formally in control of the integration process as their consent is necessary on all major decisions - not least with regard to the release of financial support to bailed-out states. The existence of this paradox only serves to reinforce the disillusionment and rejection of the EU, which is particularly acute in Southern Europe though not limited to it.

So what is to be done? The two problems are intertwined, and the solution of the one feeds into the other. The good news is that a degree of politicisation and a step back from the politics of technocracy is near inevitable if the EU is to confront the challenges of these problems effectively. A good starting point would be to reconsider the politics of extreme austerity and develop policy tools that go beyond the institutional setup to promote growth and employment. As the articles in this symposium demonstrate, the current policy course of extreme austerity has had dramatic distributional and economic circumstances, especially in Southern Europe (Overbeek, 2012, p. 42). This has led to social dislocation in countries such as Greece and Spain, and has reinforced extremist politics at the expense of both the national political class and the EU more generally. Considering that Southern European states have traditionally supported closer political integration, the ineffectiveness of extreme austerity manifests itself both economically and politically. What is more, the new institutional architecture outlined in the first section comes to strengthen the limits inherent in the original Maastricht settlement, which focused exclusively on market-based adjustment and conceptualised convergence in an overtly economic sense (Aiginger et al., 2012).

An alternative does exist, however, and comes in the form of a set of measures to lift Europe out of the crisis. Plans for a banking union (despite the manifest difficulties in 
setting it up) are a start, but they do not go far enough. The EU ought to rethink how to integrate the ambitious Europe 2020 agenda into the new governance architecture and make its laudable targets on employment, poverty reduction and social cohesion a mandatory part of convergence. To that end, the idea of a mandatory social pact as promoted by European non-governmental organisations (NGOs) is a good point of departure (European Commission, 2010; Social Platform, 2013). Moreover, some form of debt mutualisation, carefully crafted and entailing safety clauses to avoid free-riding and moral hazard problems, can and should be introduced. In fact, such a proposal was formulated a long time ago but has yet to be implemented. Finally, to avoid the danger of permanent deflation, particularly in Southern Europe, the EU should mobilise all available instruments from the ECB, the European Investment Bank (EIB) and the European Social Fund (ESF) to promote sustainable growth that will lead to employment and welfare. Unfortunately, the budget agreed for the next seven-year Multiannual Financial Framework falls way short of such an approach, despite the fact that unemployment continues to climb. A different course of political action is both possible and necessary.

Nevertheless, these proposals will hardly be enough on their own or as long as an aloof form of intergovernmentalism is practised. Instead, it is now time to strengthen the Community method and take a step back from unilateral policy initiatives that are then dressed up in communitarian language. The EU will be not only tolerated but also actively supported once it reconnects to its citizens. Yet to do this it needs to move away from the current process of simply empowering the Commission to supervise the implementation of policies that are counter-productive to the European Union's longterm interests. The recently launched European Citizens' Initiative (ECI) was a first step in the direction of citizen involvement, for instance, but it is not enough. National parliaments should be further embedded in the decision-making structure and help make subsidiarity more than a rhetorical schema. While Eurosceptic voices can often turn ugly and border on chauvinism, not all of the criticism against EU decision making is paranoid or condemnable. Such reforms would not only enhance the EU's legitimacy, they would also give material substance to Saurugger's 'circular Europeanisation' and integrate the disparate decision-making levels into a more coherent structure.

\section{Conclusions}

The Eurozone crisis is a lasting one that is full of turns and surprises. The latest example was the Cypriot bailout of March 2013, which opened up a whole new discussion about the spectrum of possible solutions in dealing with indebted members and about the safety of individual savings. The aim of this article has been to underline the key policy and institutional reforms adopted at the EU level as well as their implications for member states since 2008. It has also highlighted some of the key theoretical repercussions and lessons from the crisis as they are further developed in the articles of this symposium. Finally, it has turned to the normative discussion about the future of the EU in light of the empirical and theoretical findings.

The politics of austerity has been the main avenue promoted by the 'Euro Summit' as a way out of the crisis. A recipe promoted by the German government and supported by 
a number of member states in the absence of a consensus on more viable solutions has led to fast and often radical policy and administrative changes in the countries receiving European financial aid. Two observations can be made. The first concerns the EU institutions and the increase in coercive mechanisms and conditionality in the EU's relationship with bailout countries. Never before has the role of an international institution - namely the IMF - been so pronounced in EU politics. The second observation concerns changes at the member state level, where following the austerity rationale has led to a further shrinking of national administrations and of welfare institutions and provisions. Citizens are finding it difficult to accept this new Europe, especially in regions where until recently growth and infrastructure development had been linked to EU structural funds. The financial crisis has been transformed into a social and political crisis, and extremism is gaining ground.

We argue that the complexity of the crisis has made interdisciplinary research and the exchange of approaches, data and results across the social sciences indispensable. This symposium is a first attempt in this direction. For example, politics and economics approaches shed light on the winners and losers of the wave of public and social policy reforms in the South of Europe (Jordana; Matsaganis and Leventi). The effect of austerity policies upon the informal welfare state and thus upon the success of economic stabilisation programmes is eloquently demonstrated by Lyberaki and Tinios, building upon the economics of the family and social networks literature. Finally, Saurugger's engagement with the Europeanisation literature demonstrates the importance of deepening our understanding of changes at the EU level.

To conclude, we would argue that the intensity of the crisis and its theoretical and empirical implications have increased the need for a normative discussion about the future of Europe within academia and between disciplines. The EU and its member states are at a critical juncture and they should either move forward towards a more federal union or they will be guided to a return to intergovernmentalism. The solutions and the intermediate steps between the two directions are many and should be further discussed and explored by politicians, citizens and academics. What needs to be elucidated in the near future is a coherent vision of a future EU. Further delay in articulating that vision threatens to undermine the EU project in its entirety.

(Accepted: 28 January 2014)

\section{About the Authors}

Stella Ladi joined Queen Mary, University of London, as a Senior Lecturer in 2012. Her research interests include public policy and public administration reforms, Europeanisation, global governance and the role of experts in public policy. Some of her most recent publications are: 'Policy Change and Soft Europeanization: The Transfer of the Ombudsman Institution to Greece, Cyprus and Malta', Public Administration, 89 (4), 1643-63 (2011); 'Globalization and/or Europeanization? The Case of Flexicurity', New Political Economy, 18 (4), 480-502 (2013) (with Dimitris Tsarouhas); and 'Austerity Politics and Administrative Reform: The Eurozone Crisis and Its Impact upon Greek Public Administration', Comparative European Politics (2014). Stella Ladi, Queen Mary School of Business and Management, University of London, Francis Bancroft Building, Mile End Road, London E1 4NS, UK; email: s.ladi@qmul.ac.uk

Dimitris Tsarouhas is Acting Chair and Jean Monnet Chair in EU Politics at the Department of International Relations at Bilkent University, Turkey. He is the author of Social Democracy in Sweden: The Threat from a Globalized World (I.B. Tauris, 2008); co-editor of Bridging the Real Divide: Social and Regional Policy in Turkey's EU Accession 
Process (METU Press, 2007); and author of numerous book chapters and journal articles on European politics. His work has appeared in journals such as New Political Economy, Public Administration, Social Politics, Social Policy and Administration and Southeast European and Black Sea Studies. Dimitris Tsarouhas, Department of International Relations, Bilkent University, 06800 Ankara, Turkey; email: dimitris@bilkent.edu.tr

\section{Note}

This symposium is the result of an international conference organised by the Greek Politics Specialist Group (GPSG) and hosted by the University of Strathclyde on 8-9 December 2011 entitled 'The Politics of Extreme Austerity: Greece Beyond the Crisis'. We thank all participants of that conference for the stimulating debates, GPSG for its unwavering support, the contributors to this symposium, and last but not least, the PSR editors for the excellent cooperation and useful suggestions throughout the project.

\section{References}

Aiginger, K., Cramme, O., Ederer, S., Liddle, R. and Thillaye, R. (2012) 'Reconciling the Short and the Long Run: Governance Reforms to Solve the Crisis and Beyond', European Policy Brief. Available from: http://ec.europa.eu/ research/social-sciences/pdf/policy-briefs-www-for-europe-122012_en.pdf [Accessed 12 February 2013].

Council of the European Union (2013) 'Council Agrees General Approach to Single Resolution Mechanism'. 17602/13, 18 December. Available from: http://www.consilium.europa.eu/uedocs/cms_data/docs/pressdata/en/ecofin/140190.pdf [Accessed 24 January 2014].

Davern, M. (1997) 'Social Network and Economic Sociology: A Proposed Research Agenda for a More Complete Social Science', American Journal of Economics and Sociology, 56 (3), 287-301.

Degryse, C. (2012) 'The New European Economic Governance', ETUI Working Paper 2012.14. Brussels: ETUI.

European Commission (2008) EMU@10: Successes and Challenges after Ten Years of Economic and Monetary Union. Luxembourg: OPOCE.

European Commission (2010) 'Communication from the Commission. Europe 2020: A European Strategy for Smart, Sustainable and Inclusive Growth', COM (2010) 2020 final. Available from: http://eur-lex.europa.eu/legal-content/ EN/TXT/PDF/?uri=CELEX:52010:DC2020\&qid=1395756549777\&from=EN [Accessed 25 March 2014].

Figari, F., Iacovou, M., Skew, A. and Sutherland, H. (2012) 'Approximations to the Truth: Comparing Survey and Microsimulation Approaches to Measuring Income for Social Indicators', Social Indicators Research, 105, $387-407$.

Gros, D. (2012) 'The False Promise of a Eurozone Budget', Project Syndicate, 6 December. Available from: http:// www.project-syndicate.org/commentary/the-eurozone-needs-a-banking-union-not-a-budget-by-daniel-gros [Accessed 24 February 2013].

Jordana, J. (2014) 'Fiscal Crisis and Policy Dismantling in Spain', Political Studies Review, 12 (2), 224-38.

Ladi, S. (2014) 'Austerity Politics and Administrative Reform: The Eurozone Crisis and Its Impact upon Greek Public Administration', Comparative European Politics, 12 (2), 184-208.

Ladi, S. and Graziano, P. (2014) “ "Fast-forward” Europeanization and Welfare State Reform in Greece and Italy in Light of the Eurozone Crisis', in R. Coman, T. Kostera and L. Tomoni (eds), Europeanization and EU Integration: From Incremental to Structural Change? Basingstoke: Palgrave Macmillan (forthcoming).

Lyberaki, A. and Tinios, P. (2014) 'The Informal Welfare State and the Family: Invisible Actors in the Greek Drama', Political Studies Review, 12 (2), 193-208.

Matsaganis, M. and Leventi, C. (2014) 'Poverty and Inequality during the Great Recession in Greece', Political Studies Review, 12 (2), 209-23.

Molina, O. and Rhodes, M. (2002) 'Corporatism: The Past, Present and Future of a Concept', Annual Review of Political Science, 5, 305-31.

O’Donnell, J. (2014) 'EU Parliament Chief Warns of Flaws in Europe's Banking Union', Reuters UK, 21 January. Available from: http://uk.reuters.com/article/2014/01/21/uk-eu-banks-idUKBREA0K19O20140121 [Accessed 24 January 2014].

Overbeek, H. (2012) 'Sovereign Debt Crisis in Euroland: Root Causes and Implications for European Integration', International Spectator, 47 (1), 30-48.

Salines, M., Glöckler, G. and Truchlewski, Z. (2012) 'Existential Crisis, Incremental Response: The Eurozone's Dual Institutional Evolution, 2007-2011', Journal of European Public Policy, 19 (5), 665-81.

Saurugger, S. (2014) 'Europeanisation in Times of Crisis', Political Studies Review, 12 (2), 181-92.

Social Platform (2013) 'Letter to the EU Spring Council of March 14-15, 2013', 8 March, Brussels. Available from: http://www.socialplatform.org/wp-content/uploads/2013/06/20130314_Social-Platform_letter_Spring_Council.pdf [Accessed 10 January 2014].

Tsarouhas, D. (2012) 'Political Discourse and Path Shaping in Public Policy: Comparing Pension Reforms in Greece and Italy', Public Administration, 90 (1), 160-74.

Tsoukalis, L. (2012) 'The Political Economy of the Crisis: The End of an Era?', Global Policy, 3 (1), 42-50. 